3. Kohl S, Loo LS 1980 Ontogeny of murine cellular cytotoxicity to herpes simplex virus-infected cells. Infect Immun 30:847

4. Kohl S, Loo LS, Greenberg SB 1982 Protection of newborn mice from herpes simplex virus by human interferon, antibody and leukocytes. $\mathrm{J}$ Immunol 128:1107

5. Kohl S, Loo LS 1982 Protection of infant mice against herpes simplex virus, probable in vivo antibody-dependent cellular cytotoxicity. $\mathbf{J}$ Immunol 129:370

6. Kohl S 1983 Stimulation of human natural killer cytotoxicity and protection of mice from infection due to herpes simplex virus by recombinant human leukocyte interferon. J Infect Dis 147:484

7. Kohl S, Loo LS, Pickering LK 1981 Protection of neonatal mice against herpes simplex viral infection by human antibody and leukocytes from adult but not neonatal humans. J Immunol 127:1273

8. Goeddel DV, Yelverton E, Ullrich A, et al 1980 Human leukocyte interferon produced by $E$. coli is biologically active. Nature $287: 411$

9. Staehelin T, Hobbs DS, Kung H, et al 1981. Purification and characterization of recombinant human leukocyte interferon (IFLrA) with monoclonal antibodies. J Biol Chem 256:9750

10. Kohl S 1983 Defective infant natural killer cytotoxicity (NKC) and antibodydependent cellular cytotoxicity (ADCC) to herpes simplex virus (HSV)infected cells. J Pediatr 102:885

11. Blalock JE, Baron S 1977 Interferon-induced transfer of viral resistance between animal cells. Nature 269:422

12. Whitley RJ, Nahmias AF, Soong SJ, et al 1980 Vidarabine therapy of neonatal herpes simplex infection. Pediatrics 66:495

13. Offit PA, Starr SE, Zolnick $P$, et al 1982 Acyclovir therapy in neonatal herpes simplex infection. Pediatr Infect Dis $1: 253$

14. Kohl S 1983 Additive effect of acyclovir and immune transfer in neonatal herpes simplex infection in mice. Infect Immunol 39:480

\title{
Measurement of Cardiopulmonary Function by Rebreathing Methodology in Piglets
}

\author{
WILLIAM M. MENTZ, EDWARD E. LAWSON, AND MITCHELL FRIEDMAN
}

Departments of Medicine and Pediatrics, University of North Carolina, Chapel Hill, North Carolina 27514

\begin{abstract}
The use of a multiple gas rebreathing method for the measurement of cardiopulmonary function in mechanically ventilated neonates was evaluated. The following indices of cardiopulmonary function were assessed in $\mathbf{2 0}$ piglets (mean weight, $2.3 \mathrm{~kg}$ ): 1) pulmonary capillary blood flow $\left.\left(\dot{Q}_{c}\right), 2\right)$ diffusing capacity for carbon monoxide $\left.\left(D_{L} \mathrm{CO}\right), 3\right)$ lung gas volume (FRC), 4) oxygen consumption $\left(\dot{V}_{\mathrm{O}_{2}}\right)$, and 5) volume of the pulmonary tissues and capillaries (VTPC), the latter an estimate of total lung water. During mechanical ventilation at zero end expiratory pressure, all rebreathing parameters correlated well with body weight. Additionally, a good correlation $(r=0.81$, slope = 0.99 ) between VTPC and postmortem estimate of total lung water was observed. The effect of ventilation with positive end expiratory pressure (PEEP) was then studied in 10 piglets. On increasing PEEP from zero to $15 \mathrm{~cm}$ $\mathrm{H}_{2} \mathrm{O}$, FRC significantly increased by $208 \%, \dot{Q}_{c}$ significantly decreased by $60 \%$, and no changes in VTPC occurred. Seven piglets were then studied after induction of lung injury by oleic acid infusion. Compared with the preoleic acid infusion values, all the rebreathing variables decreased during ventilation without PEEP. Unlike the situation with the normal piglets, when PEEP was increased from zero to $10 \mathrm{~cm} \mathrm{H}_{2} \mathrm{O}$ in the oleic acid-infused piglets, the values for FRC and VTPC significantly increased. Mean VTPC at $10 \mathrm{~cm} \mathrm{H}_{2} \mathrm{O}$ was $20 \pm 2 \mathrm{ml} / \mathrm{kg}$ which correlated well $(r=0.93)$ with the postmortem total lung water value of $19 \pm 1 \mathrm{~g} / \mathrm{kg}$. Thus, multiple gas rebreathing methodology is applicable to studies using
\end{abstract}

Received December 8, 1983: accepted May 10,1984.

Reprint requests may be addressed to Dr. Mitchell Friedman, Department of Medicine, Division of Pulmonary Diseases, 724 Burnett-Womack Bldg. 229H, Chapel Hill, NC 27514

This work was partially supported by the following grants: HD 13280, HD 00475, and United Cerebral Palsy (R-317-80). W.M.M. was supported by a fellowship from the Parker B. Francis Foundation. small animals. The observation that the application of PEEP in lung injury increased the accuracy of the VTPC measurement suggests that PEEP improves ventilation of injured lung segments. (Pediatr Res 18:1167-1172, 1984)

\section{Abbreviations}

$\dot{Q}_{c}$, pulmonary capillary flow

$D_{L} \mathrm{CO}$, diffusing capacity for carbon monoxide

$\dot{V}_{\mathrm{O}_{2}}$, oxygen consumption

FRC, lung volume

VTPC, volume of pulmonary tissue and capillary blood PEEP, positive end expiratory pressure BW, body weight

The noninvasive multiple gas rebreathing method (19) allows for easily repeatable, accurate, and rapid measurement of several indices of cardiopulmonary function including $\dot{Q}_{c}, D_{L} \mathrm{CO}, \dot{V}_{\mathrm{O}_{2}}$, FRC, and VTPC, the latter measurement an accurate estimate of total lung water $(10,12)$. This technique has been used in large animals (dogs, sheep) as well as humans (3, 10, 11, 13, 16, $18,19,21)$. Presently, the measurement of these cardiopulmonary indices in human neonates, utilizing standard invasive techniques, is limited by the size of the vascular access, the necessity to repetitively disconnect the patient from a ventilator, and by the time required to make the measurements (20).

The purpose of the present study was to evaluate the feasibility of applying rebreathing methodology to piglets, a small animal similar in size to a human neonate, and with collateral ventilation similar to humans (8). Since PEEP is a commonly used treatment modality in neonatal lung injury, we also evaluated the effects of PEEP on rebreathing parameters in normal piglets and also in piglets with oleic acid-induced lung injury. 


\section{MATERIALS AND METHODS}

Twenty newborn piglets, ages 2-20 days, with a mean body weight of $2.3 \mathrm{~kg}$ (range, $1.4-4.8 \mathrm{~kg}$ ) were anesthetized with intravenous chloralose $(40 \mathrm{mg} / \mathrm{kg})$, urethane $(250 \mathrm{mg} / \mathrm{kg})$, and intramuscular ketamine $(10 \mathrm{mg} / \mathrm{kg})$. Catheters were placed in a jugular vein and femoral artery. Systemic arterial pressure was monitored using a transducer referred to the midchest level (model 1280C, Hewlett-Packard, Waltham, MA). The trachea was then surgically exposed and cut horizontally. A size 12 French polyvinyl tube was inserted in the distal trachea and secured with two silk ligatures. Body temperature was measured by a rectal probe and maintained at $39^{\circ} \mathrm{C}$ utilizing a servocontrolled heating lamp. The piglet was then paralyzed with intravenous pancuronium bromide $(0.2 \mathrm{mg} / \mathrm{kg})$ and placed on a constant volume ventilator (EDCO Scientific, Inc., Chapel Hill, $\mathrm{NC}$ ) with a tidal volume of $30 \mathrm{ml} / \mathrm{kg}$ and the respiratory rate was adjusted to maintain a $\mathrm{PaCO}_{2}$ of $35-40$ torr. $\mathrm{PaO}_{2}, \mathrm{PaCO}_{2}$, and $\mathrm{pH}$ in arterial blood were measured using standard electrodes (Radiometer model BM SBMK2, Copenhagen, Denmark). In several animals, including normal piglets and piglets with lung injury, airway pressure was monitored throughout the experiment.

The rebreathing apparatus consisted of a $150-\mathrm{ml}$ rubber bagin-bottle and valve developed by Gallioto et al. (13) with a total dead space of $2 \mathrm{ml}$. The valve was interposed between the piglet's airway opening and the ventilator. By turning the valve, the inspiratory gas flow from the ventilator could be rapidly switched to the bag-in-bottle system allowing the animal to be rebreathed with the test gas mixture contained in the bag. The test gas mixture contained $0.3 \% \mathrm{C}^{18} \mathrm{O}, 0.8 \% \mathrm{C}_{2} \mathrm{H}_{2}, 10 \% \mathrm{He}, 21 \% \mathrm{O}_{2}$, and the balance $\mathrm{N}_{2}$. Rebreathing was initiated at the end of expiration and continued at a rate of 30 breaths/min for $20 \mathrm{~s}$. The gases were continuously sampled at the airway opening by a mass spectrometer with a sampling rate of $15 \mathrm{ml} / \mathrm{min}$ (MGA 1100, Perkin-Elmer Corp, Pomona, CA). The analog signals from the mass spectrometer were directed to a small computer (MINC-11, Digital Equipment Corp., Maynard, MA). The computer digitized the analog signals for the gases at a rate of 15 points/s correcting each value of $\mathrm{C}_{2} \mathrm{H}_{2}$ and $\mathrm{C}^{18} \mathrm{O}$ for helium dilution. The program calculated the slope of the disappearance curves of $\mathrm{C}^{18} \mathrm{O}$ and $\mathrm{C}_{2} \mathrm{H}_{2}$ after the point of minimal oscillation of the helium tracing (19). Data was analyzed for three consecutive breaths after this starting point using the algorithm of Sackner et al. (19). All rebreathing runs were done in triplicate and averaged (10). No correction was made for gas back pressure, which was always $<5 \%$ of the inspired gas concentrations ( 10 , 12).

In preliminary experiments, we found a rebreathing volume of $60 \mathrm{ml}$ for piglets weighing $0-2 \mathrm{~kg}, 80 \mathrm{ml}$ for $2-4-\mathrm{kg}$ piglets, and $100 \mathrm{ml}$ for $4-6-\mathrm{kg}$ piglets to be optimal in regard to reproducibility and accuracy of measurements. This is similar to rebreathing volumes per body weight used by us and others in dogs and humans $(10,11,16,19)$. Thirteen piglets were studied at zero end expiratory pressure. Ten of these animals were then ventilated with varying levels of PEEP $\left(5,10,15 \mathrm{~cm} \mathrm{H}_{2} \mathrm{O}\right)$ and repeat rebreathing measurements were made while on PEEP (normal lung group). The various levels of PEEP were applied in differing sequences; and continued for a 10 - to 15 -min period before any measurements were performed. PEEP was applied by immersing the expiratory limb of the ventilator under water. Since the rebreathing measurement begins at end expiration in a closed system, the rebreathing method would not increase end expiratory pressure. Seven animals were again ventilated at zero end expiratory pressure and had repeat baseline rebreathing measurements performed. These seven piglets were then given an infusion of $0.05 \mathrm{ml} / \mathrm{kg}$ oleic acid via the jugular vein (lung injury group). Repeat rebreathing measurements were made 15 min after the oleic acid injection during ventilation with zero end expiratory pressure and then with the application of various levels of PEEP. Again, the various levels of PEEP were administered in randomly differing sequences as described previously in order to minimize the effect of increasing lung water during the measurement period as a result of the injury. At the conclusion of the last rebreathing measurement, the piglet was killed with an intravenous injection of $\mathrm{KCl}$. The chest was rapidly opened and the lungs removed. All blood was allowed to drain passively from the lungs and then weighed (total wet weight). The lungs were then placed in an $80^{\circ} \mathrm{C}$ oven and dried until no further change in weight occurred (dry weight). Wet minus dry lung weight was then calculated and compared to VTPC. The justification for this comparison has been discussed in a previous publication (10).

Statistical analysis to compare the different levels of PEEP with baseline values was performed by using Dunnet's least squares difference for multiple comparisons (7). Comparison between PEEP levels on rebreathing parameters was tested by the Scheffe test (24). Linear regressions were calculated using standard algorithms. All data are expressed as the mean \pm the standard error of the mean. $p$ values $<0.05$ were considered to be significant.

\section{RESULTS}

Figure 1 shows the data obtained for the various rebreathing parameters versus body weight in all 20 animals at zero end expiratory pressure. The linear regressions of the various rebreathing parameters with body weight are shown. The average coefficient of variation for each rebreathing parameter was $D_{L} \mathrm{CO}$ (8\%), VTPC $(11 \%), \dot{Q}_{c}(8 \%)$, FRC $(5 \%)$, and $\dot{V}_{2}(5 \%)$, demonstrating good reproducibility of the method.

Normal lung group. Table 1 lists the results obtained in the piglets for $D_{L} \mathrm{CO}$, VTPC, $\dot{Q}_{c}, \mathrm{FRC}$, and $\dot{V}_{\mathrm{O}_{2}}$ at the various levels
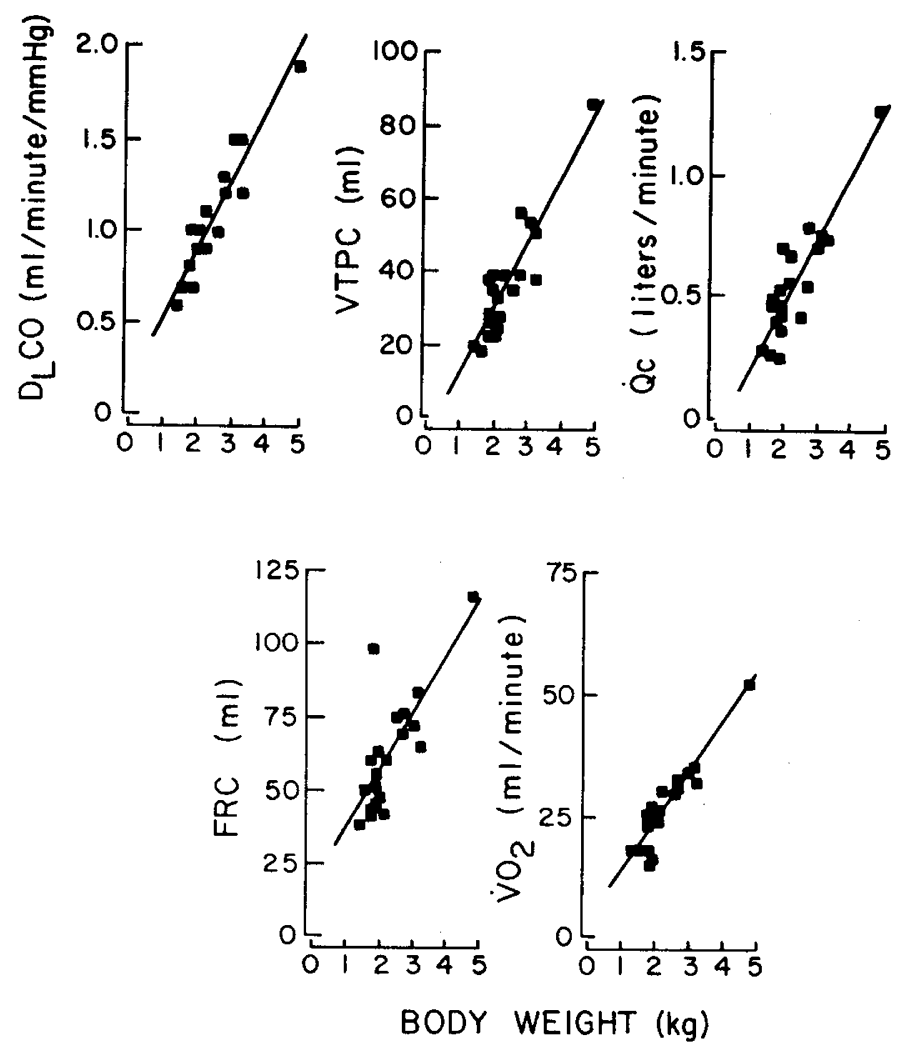

Fig. 1. Correlation of the various rebreathing parameters with BW. The regression equations and correlation coefficients $(r)$ are: $\dot{Q}_{c}=-0.07$ $+0.27 \times \mathrm{BW}(r=0.80), D_{L} \mathrm{CO}=0.15+0.39 \times \mathrm{BW}(r=0.94), \mathrm{FRC}=$ $17.63+19.49 \times \mathrm{BW}(r=0.76), \dot{V}_{\mathrm{O}_{2}}=3.30+10.16 \times \mathrm{BW}$, and VTPC $=-6.13+18.60 \times \mathrm{BW}(r=0.90)$. 
of PEEP. Increasing the level of PEEP, from 0 to $15 \mathrm{~cm} \mathrm{H}_{2} \mathrm{O}$, resulted in a progressive significant increase in FRC and a decrease in $\dot{Q}_{c}$. No significant changes in VTPC occurred at any level of PEEP compared to the zero PEEP baseline value. The absolute magnitude of $D_{L}$ CO increased significantly at the $15 \mathrm{~cm}$ $\mathrm{H}_{2} \mathrm{O}$ PEEP level as compared to the zero PEEP value. $D_{L} \mathrm{CO}$ when computed per unit lung volume decreased with increasing

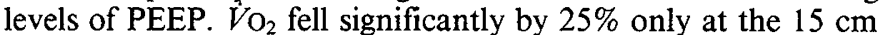
$\mathrm{H}_{2} \mathrm{O}$ PEEP level. Only four piglets could be successfully ventilated at a level of $15 \mathrm{~cm} \mathrm{H}_{2} \mathrm{O}$ PEEP long enough to obtain rebreathing measurements. The remainder of the animals developed pneumothoraces at this high level of PEEP as determined by chest wall transillumination and marked decreases in FRC.

The accuracy of the rebreathing VTPC measurement was determined by comparison with the postmortem wet minus dry lung weights. Figure 2 shows the linear regression for VTPC with wet minus dry lung weight in the normal piglets $(r=0.80 ; p<$ $0.01)$. Total wet minus dry weight averaged $79.2 \pm 1.2 \%$ of total wet weight. Mean wet minus dry lung weight $/ \mathrm{kg}$ body weight was $12.66 \pm 0.60$. Rebreathing measurements of $\dot{Q}_{c}$ were also compared to simultaneously obtained cardiac outputs using a standard indicator dilution technique following injection of indocyanine green $\left(\dot{Q}_{T}\right)$ during rebreathing. In two piglets, mean $\dot{Q}_{c}$ of six determinations was $0.59 \pm 0.03 \mathrm{liter} / \mathrm{min}$ as determined by the rebreathing technique and was $0.67 \pm 0.05 \mathrm{liter} / \mathrm{min}$ as determined by dye dilution. The linear regression of $\dot{Q}_{c}$ versus $\dot{Q}_{T}$ was $\dot{Q}_{c}=0.19+0.60 \times \dot{Q}_{T}(r=0.98)$.

Lung injury group. Table 2 lists the rebreathing values obtained in four piglets ventilated at zero end expiratory pressure following oleic acid infusion. Paired comparison of these values with those of the baseline pre-oleic acid values (data not shown) revealed significant parallel decreases in $D_{L}$ CO $(14 \pm 4 \%)$, VTPC (14 \pm

Table 1. Effect of PEEP on normal lungs*

\begin{tabular}{ccccccc}
\hline $\begin{array}{c}\text { PEEP } \\
\left(\mathrm{cm} \mathrm{H} \mathrm{H}_{2} \mathrm{O}\right)\end{array}$ & $n$ & $\begin{array}{c}D_{L} \mathrm{CO} \\
(\mathrm{ml} / \mathrm{min} / \mathrm{mm} \\
\mathrm{Hg} / \mathrm{kg})\end{array}$ & $\begin{array}{c}\text { VTPC } \\
(\mathrm{ml} / \mathrm{kg})\end{array}$ & $\begin{array}{c}\dot{Q}_{c} \\
\mathrm{~min} / \mathrm{kg})\end{array}$ & $\begin{array}{c}\mathrm{FRC} \\
(\mathrm{ml} / \mathrm{kg})\end{array}$ & $\begin{array}{c}\dot{V}_{\mathrm{O}_{2}} \\
(\mathrm{ml} / \mathrm{min} / \mathrm{kg})\end{array}$ \\
\hline 0 & 10 & $0.44 \pm 0.02$ & $16 \pm 1$ & $0.25 \pm 0.02$ & $26 \pm 1$ & $12 \pm 1$ \\
10 & 8 & $0.48 \pm 0.03$ & $15 \pm 1$ & $0.17 \pm 0.01 \dagger$ & $44 \pm 3 \dagger$ & $11 \pm 1$ \\
15 & 8 & $0.49 \pm 0.02$ & $15 \pm 1$ & $0.14 \pm 0.02 \dagger$ & $63 \pm 2 \dagger$ & $11 \pm 1$ \\
\hline
\end{tabular}

* Data shown as $\bar{x} \pm$ SEM.

$\dagger$ Significant change $(p<0.05)$ from the values obtained at zero end expiratory pressure.

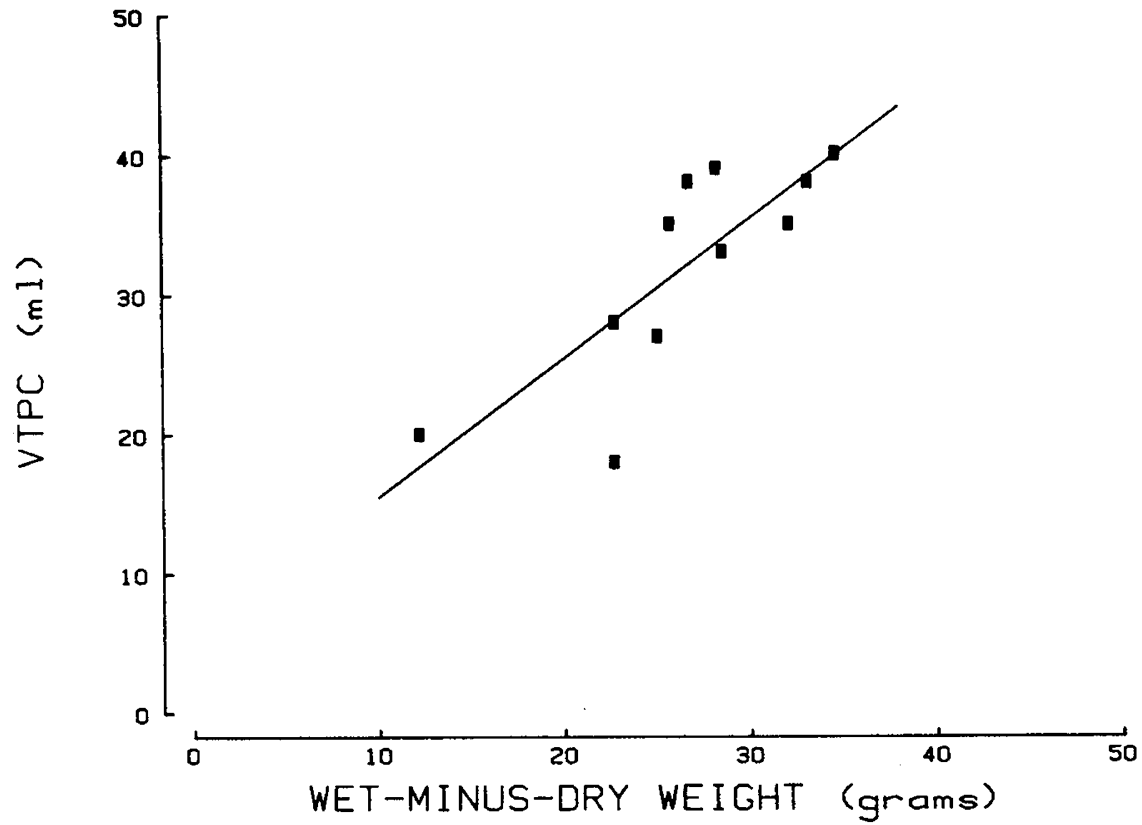

Fig. 2. Graphic representation of the relationship between VTPC and wet minus dry weight in the 11 normal piglets. VTPC was measured during ventilation at zero end expiratory pressure $(r=0.81$; slope $=0.99)$.

Table 2. Effect of PEEP on edematous lungs*

\begin{tabular}{ccccccc}
\hline $\begin{array}{c}\text { PEEP } \\
\left(\mathrm{cm} \mathrm{H} \mathrm{H}_{2} \mathrm{O}\right)\end{array}$ & $n$ & $\begin{array}{c}D_{L} \mathrm{CO} \\
(\mathrm{ml} / \mathrm{min} / \mathrm{mm}\end{array}$ & $\begin{array}{c}\text { VTPC } \\
\mathrm{Hg} / \mathrm{kg})\end{array}$ & $\begin{array}{c}\dot{Q}_{c} \\
(\mathrm{liter} / \\
\mathrm{min} / \mathrm{kg})\end{array}$ & $\begin{array}{c}\mathrm{FRC} \\
(\mathrm{ml} / \mathrm{kg})\end{array}$ & $\begin{array}{c}\dot{V O}_{2} \\
(\mathrm{ml} / \mathrm{min} / \mathrm{kg})\end{array}$ \\
\hline 0 & 4 & $0.38 \pm 0.04$ & $14 \pm 4$ & $0.19 \pm 0.03$ & $22 \pm 2$ & $12 \pm 1$ \\
10 & 7 & $0.44 \pm 0.05$ & $15 \pm 1$ & $0.14 \pm 0.02$ & $37 \pm 2 \dagger$ & $10 \pm 1$ \\
15 & 7 & $0.48 \pm 0.03$ & $19 \pm 1 \dagger$ & $0.11 \pm 0.03 \dagger$ & $61 \pm 2 \dagger$ & $9 \pm 1$ \\
\hline
\end{tabular}

* Data shown as $\bar{x} \pm$ SEM.

$\dagger$ Significant change $(p<0.05)$ from the values obtained at zero end expiratory pressure.

$\ddagger$ Significantly different from the 0 and $5 \mathrm{~cm} \mathrm{H}_{2} \mathrm{O}$ PEEP level but not from the $10 \mathrm{~cm} \mathrm{H}_{2} \mathrm{O}$ PEEP level. 
$6 \%), \dot{Q}_{c}(20 \pm 3 \%)$, and FRC $(15 \pm 5 \%)$ with no change in $\dot{V}_{\mathrm{O}_{2}}$. The VTPC value determined at zero end expiratory pressure following the oleic acid infusion significantly underestimated the final postmortem wet minus dry lung weight in these four animals by an average of $32 \pm 7 \%$. The three other piglets in this lung injury group developed pneumothoraces when on $15 \mathrm{~cm}$ $\mathrm{H}_{2} \mathrm{O}$ PEEP, necessitating discontinuance of the study prior to obtaining the zero PEEP rebreathing parameters.

Table 2 also shows the values of the rebreathing parameters obtained in all seven piglets studied while at varying levels of PEEP following oleic acid infusion. There was no significant change in arterial blood gases or arterial pressure during the experiment following oleic acid injection except for a significant increase in $\mathrm{PO}_{2}$ (mean increase of $32 \%$ ) when PEEP was increased from zero to $5 \mathrm{~cm} \mathrm{H}_{2} \mathrm{O}$ PEEP. No significant changes in arterial blood gases or systemic blood pressure at other levels of PEEP were noted (data not shown). FRC significantly increased $68 \%$ on increasing PEEP from zero to $5 \mathrm{~cm} \mathrm{H}_{2} \mathrm{O}$ and an additional $40 \%$ when PEEP was increased from 5 to $10 \mathrm{~cm} \mathrm{H}_{2} \mathrm{O}$. No significant change in FRC occurred when PEEP was increased from 10 to $15 \mathrm{~cm} \mathrm{H} \mathrm{H}_{2} \mathrm{O}$. $\dot{Q}_{\text {c }}$ fell at each higher level of PEEP including the change from 10 to $15 \mathrm{~cm} \mathrm{H}_{2} \mathrm{O}$ PEEP. The changes observed in $D_{L}$ CO with the different PEEP levels were not sig. nificantly different from the control value. As in the noninjured group, a significant decrease in $\dot{V O}_{2}(50 \%)$ was noted only at the $15 \mathrm{~cm} \mathrm{H}_{2} \mathrm{O}$ PEEP level. Following oleic acid injury VTPC did not change significantly on changing PEEP from zero to $5 \mathrm{~cm}$ $\mathrm{H}_{2} \mathrm{O}$. However, in contrast to the effects of PEEP on normal lungs, a significant increase in VTPC at the $10 \mathrm{~cm} \mathrm{H}_{2} \mathrm{O}$ PEEP level was observed compared to the value obtained at zero PEEP. Similar to the observed effects of PEEP on FRC with this group, the change in VTPC on changing PEEP from 10 to $15 \mathrm{~cm} \mathrm{H}_{2} \mathrm{O}$ was not significant. Since the rebreathing determination of VTPC was obtained in all seven animals in this group at $10 \mathrm{~cm} \mathrm{H}_{2} \mathrm{O}$ PEEP, and since no further significant change in VTPC occurred when PEEP was increased from the 10 to $15 \mathrm{~cm} \mathrm{H}_{2} \mathrm{O}$ PEEP level, we chose the VTPC value calculated at $10 \mathrm{~cm} \mathrm{H}_{2} \mathrm{O}$ PEEP for the comparison with postmortem wet minus dry lung weight (Fig. 3). The relationship of VTPC and wet minus dry lung weight for these animals is clearly linear $(r=0.93 ; p<0.01$; slope $=1.0$ ). The correlation coefficients for VTPC and wet minus dry lung weights was $0.58(p=N S), 0.57(p=N S)$, and $0.98(p<0.001)$ for the 0,5 , and $15 \mathrm{~cm} \mathrm{H}_{2} \mathrm{O}$ PEEP levels, respectively. The VTPC determinations made at $10 \mathrm{~cm} \mathrm{H}_{2} \mathrm{O}$
PEEP were $98 \pm 7 \%$ of the postmortem wet minus dry lung weights and had increased by an average of $35 \%$ over pre-oleic acid values. Total wet minus dry lung weight in this group was $83 \pm 1 \%$ of the total wet weight. Wet minus dry lung weight $/ \mathrm{kg}$ body weight was $19.7 \pm 1.7$.

\section{DISCUSSION}

We have successfully applied rebreathing methodology to measure indices of cardiopulmonary function in normal newborn piglets and also during oleic acid-induced pulmonary edema. This technique allows for on-line, rapid, safe, and easily repeatable assessment of cardiopulmonary function.

Takezawa et al. (20) used a modified single-breath method to measure $D_{L}$ Co in rabbits $(1.3-3.5 \mathrm{~kg})$ which are comparable in weight to the piglets in this study. $D_{L}$ CO by their method was $0.52 \mathrm{ml} / \mathrm{min} / \mathrm{mm} \mathrm{Hg} / \mathrm{kg}$. Watanabe and Frank (23), using a single-breath $D_{L}$ CO method in cats similar in size to the piglets in this study, found the $D_{L}$ CO to be $0.41 \mathrm{ml} / \mathrm{min} / \mathrm{mm} \mathrm{Hg} / \mathrm{kg}$. Both of these reported values are comparable to the $0.44 \mathrm{ml} /$ $\mathrm{min} / \mathrm{mm} \mathrm{Hg} / \mathrm{kg}$ value that we obtained in piglets. In our experiments, the first determination of $D_{L}$ CO was not significantly different from any of the subsequent measurements made (at least two) in the normal lung, no PEEP group. Similar to previous reports, this suggests that there was no significant accumulation of $\mathrm{C}^{18} \mathrm{O}$ in the blood leading to an underestimation of $D_{L} \mathrm{CO}(10$, 11, 19). Watanabe and Frank (23) also measured FRC by neon dilution in cats and obtained a value of $26 \mathrm{ml} / \mathrm{kg}$ which also compares favorably with the $30 \mathrm{ml} / \mathrm{kg}$ we found in piglets. As measured by rebreathing at zero end expiratory pressure, VTPC correlated well with the postmortem estimate of total lung water in the normal piglets (Fig. 2). This finding is similar to data reported previously from our laboratory in normal adult dogs $(10,12)$. The effects of PEEP on normal lungs was predictable and similar to that found in larger animals, i.e. an increase in lung volume and decrease in pulmonary capillary blood flow (4, $9,12)$. $D_{L}$ CO computed per unit lung volume decreased with increasing levels of PEEP suggesting creation of lung zones in which alveolar pressure exceeded arterial pressure, as would be expected with the application of PEEP. The decrement in pulmonary capillary blood flow with PEEP is similar to that reported by us and others $(3,4,9,12)$ and the decrement in $\dot{Q}_{c}$ with oleic acid infusion and PEEP is similar to previously reported values from our laboratory in dogs (9). These data suggest that the rebreathing volumes used and airway pressures developed during

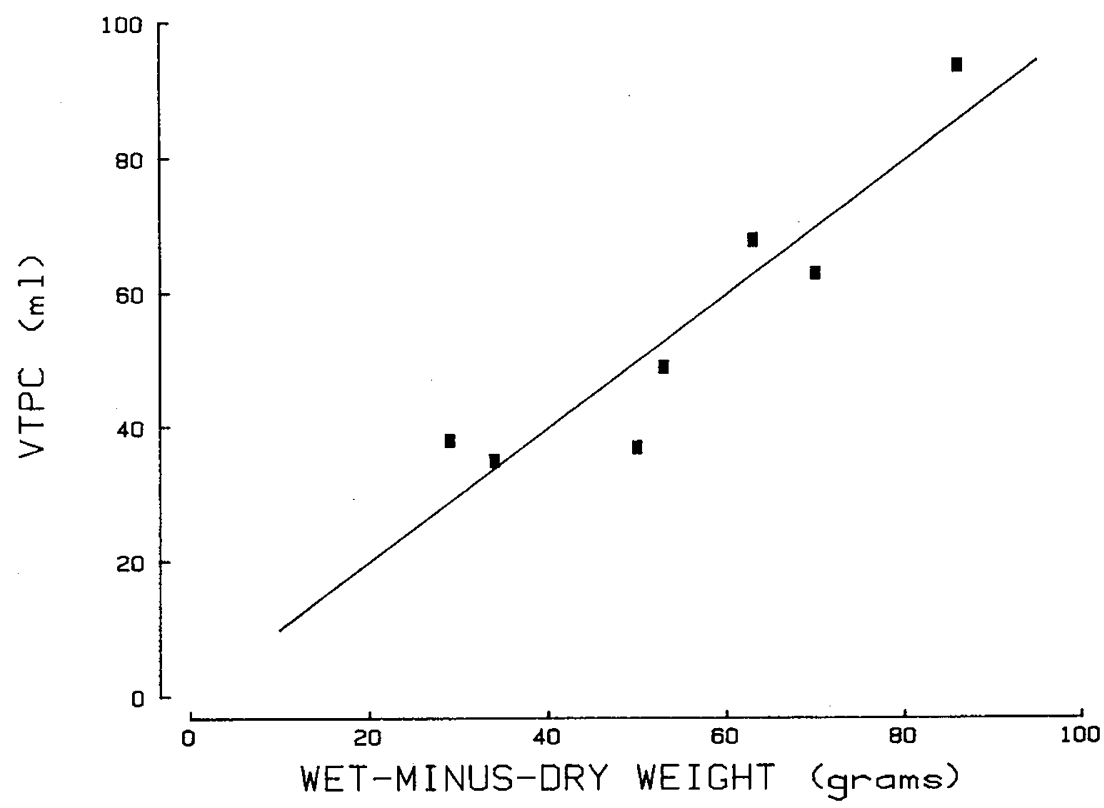

Fig. 3. Graphic representation of the relationship between VTPC and wet minus dry weight in the seven piglets following oleic acid lung injury. VTPC was measured during ventilation at $10 \mathrm{~cm} \mathrm{H}_{2} \mathrm{O}$ PEEP $(r=0.93)$. 
the rebreathing maneuver in the present study were not excessive. Although we did not measure airway pressure directly in every experiment, when it was measured it did not exceed the pressures measured prior to or following the rebreathing maneuver.

The rebreathing measurement of VTPC, $\dot{Q}_{c}, \mathrm{FRC}$, and $D_{L} \mathrm{CO}$ at zero end expiratory pressure all decreased by an average of $16 \%$ following oleic acid infusion as compared to the pre-oleic acid infusion values. The rebreathing technique is dependent upon the ability of the test gas to reach gas exchange areas of the lung and is not perfusion dependent to any great degree (17). In this acute lung injury model, whose collateral ventilation is similar to humans (8), our findings of decreased FRC and underestimation of VTPC at zero end expiratory pressure after induction of lung edema suggests loss of gas exchange units secondary to the oleic acid-induced injury, with inability of the test gas to reach these involved units. Dogs, in which most of the previous studies of the applicability of rebreathing methodology in pulmonary edema have been performed $(9,10,16)$, have a much more developed degree of collateral ventilation. This possibly explains the better correlation of VTPC with gravimetric lung water without the application of PEEP in dogs with lung injury $(10,16)$. The application of PEEP (up to $10 \mathrm{~cm} \mathrm{H}_{2} \mathrm{O}$ ) following oleic acid lung injury resulted in a significant increase of FRC indicating lung expansion. In the normal piglets, application of PEEP did not significantly affect the VTPC measurement. In contrast, VTPC significantly increased on changing the end expiratory pressure from zero to $10 \mathrm{~cm} \mathrm{H}_{2} \mathrm{O}$ in the oleic acid-treated piglets. The VTPC measurement at $10 \mathrm{~cm} \mathrm{H}_{2} \mathrm{O}$ PEEP correlated well with the postmortem estimate of total lung water in this group of animals with pulmonary edema (Fig. 3). We do not feel that this was simply due to an accumulation of lung water with time after oleic acid infusion since we varied the sequence of the levels of PEEP in the experimental protocol. The good correlation of VTPC with the autopsy determination of total lung water suggests that PEEP improves the accuracy of the rebreathing VTPC determinations in lung injury mainly by recruiting poorly ventilated injured gas exchange units rather than overdistending more normal gas exchange units, in which instance VTPC would not be expected to increase. This latter hypothesis is supported by the finding that the VTPC measurement was accurate at zero end expiratory pressure in the normal piglets (Fig. 2) and did not increase with the application of PEEP in these normal animals (Table 1).

The published effects of PEEP on lung water content are varied. A previous study from our laboratory demonstrated no increase in rebreathing measurements of VTPC or in gravimetric lung water content with PEEP. This conclusion is also supported by other investigators that report no change in lung water utilizing measurements of gravimetric lung water or transvascular fluid filtration rates with the application of PEEP $(12,14,25)$. Others have noted an increase in the amount of lung water with PEEP under certain specific experimental conditions $(1,6,15)$. Our findings regarding rebreathing measurements of VTPC in piglets in this study as well as in dogs in a previous study from our laboratory (12) does differ from the study by Cassidy et al. (3), who reported an increase in rebreathing VTPC in humans with the application of $10 \mathrm{~cm} \mathrm{H}_{2} \mathrm{O}$ PEEP. We cannot explain the difference between these studies. Our present study directly compared gravimetric lung water measurements to rebreathing measurements of VTPC, and demonstrated no increase in VTPC or in gravimetric lung water content with PEEP.

Interestingly, $\dot{V}_{\mathrm{O}_{2}}$ fell significantly at the $15 \mathrm{~cm} \mathrm{H}_{2} \mathrm{O}$ PEEP level in both the normal and lung injury groups. Tucker and Murray (22) have shown that PEEP induces changes in distribution of peripheral blood flow which might then compromise oxygen delivery to some organs. Also, oxygen uptake has been shown to be reduced in patients with adult respiratory distress syndrome who are being ventilated with PEEP (5). Danek et al. (5) suggested that the reduction in oxygen uptake was related to decreases in peripheral blood flow, an inability to utilize oxygen at the cellular level, or a combination of both effects. It is interesting to speculate that the decreased $\dot{V}_{\mathrm{O}_{2}}$ observed at $15 \mathrm{~cm}$ $\mathrm{H}_{2} \mathrm{O}$ PEEP in the piglets was related to decreased oxygen delivery secondary to the observed very low $\dot{Q}_{c}$.

The use of this rebreathing technique thus allows for accurate measurement of cardiopulmonary indices in small animals that would otherwise have required a more invasive approach or repetitive disconnection from a ventilator. Additionally, the application of PEEP appeared to improve the accuracy of rebreathing measurements in injured lungs presumably by improving the ventilation to injured lung gas exchange units. These data also suggest that rebreathing methodology can be used to noninvasively estimate cardiopulmonary function in humans of similar size, i.e. neonates, and possibly aid in determining the levels of PEEP which result in optimal gas exchange in these infants.

Acknowledgments. The authors thank R. B. Steinbach and A. R. Gratta of the North Carolina Memorial Hospital Respiratory Therapy Department for their assistance, Harriette Nichols for her technical assistance, and Mary Bates for her secretarial support.

\section{REFERENCES}

1. Albert RK, Lakshminaryan S, Kirk W, Butler J 1980 Lung inflation can cause pulmonary edema in zone 1 of in situ dogs. J Appl Physiol Respir Environ Exercise Physiol 49:815

2. Cander L, Forster RF 1959 Determination of pulmonary parenchymal tissue volume and pulmonary capillary blood flow in man. J Appl Physiol 14:541

3. Cassidy SS, Eschenbacher WI, Robertson CH, Nixon JV, Blomquist G, Johnson RL 1979 Cardiovascular effects of positive-pressure ventilation in normal subjects. J Appl Physiol Respir Environ Exercise Physiol 47:453

4. Cassidy SS, Robertson CH Jr, Pierce AK, Johnson RL Jr 1978 Cardiovascular effects of positive end-expiratory pressure in dogs. J Appl Physiol Respir Environ Exercise Physiol 44:743

5. Danek SJ, Lynch JP, Weg JG, Dantzker DR 1980 The dependence of oxygen uptake on oxygen delivery in the adult respiratory distress syndrome. Am Rev Respir Dis 122:387

6. Demling RH, Staub NC, Edmonds LH Jr 1975 Effect of end-expiratory airway pressure on accumulation of extravascular lung water. J Appl Physiol 38:907

7. Dunnett $\mathrm{CW} 1955 \mathrm{~A}$ multivariate comparison for comparing several treatments with a control. J Am Statist Assoc 50:1096

8. Fenley DC, Picken J, Welchel L, Ruff F, Corry PM, Macklem PT 1972 Blood gas transfer after small airway obstruction in the dog and minipig. Respir Physiol 15:39

9. Friedman M, Gammon K 1981 Comparison of the effects of pre- and postinjury applications of positive end expiratory pressure (PEEP). Am Rev Respir Dis 123:256

10. Friedman M, Kaufman SH, Wilkins SA Jr 1980 Analysis of rebreathing measurements of pulmonary tissue volume in pulmonary edema. $J$ Appl Physiol Respir Environ Exercise Physiol 48:66

11. Friedman M, Kovitz KL, Miller SD, Marks M, Sackner MA 1979 Hemodynamics in teenagers and asthmatic children during exercise. J Appl Physiol Respir Environ Exercise Physiol 46:293

12. Friedman M, Wilkins SA Jr, Rothfeld AF, Bromberg PA 1984 Effect of ventilation and perfusion imbalance on inert gas rebreathing variables. $J$ Appl Physiol Respir Environ Exercise Physiol 56:364

13. Gallioto FM, Brudno DS, Howard RH, Rivera O, Ruttiman UE 1981 New small volume rebreathing system to measure cardiopulmonary function. Pediatr Res 15:463

14. Hopewell PC, Murray JF 1976 Effects of continuous positive-pressure ventilation in experimental pulmonary edema. J Appl Physiol 40:568

15. Johnson RL, Cassidy SS, Haynes M, Reynolds RL, Schulz W 1981 Microvascular injury distal to unilateral pulmonary artery occlusion. J Appl Physiol Respir Environ Exercise Physiol 51:845

16. Peterson BT, Petrini MF, Hyde RW, Schreiner BF 1978 Pulmonary tissue volume in dogs during pulmonary edema. J Appl Physiol Respir Environ Exercise Physiol 44:782

17. Petrini MF, Peterson BT, Hyde RW 1978 Lung tissue volume and blood flow by rebreathing: theory. J Appl Physiol Respir Environ Exercise Physiol 44:795

18. Reinhart ME, Hughes JR, Kung M, Abraham WM, Ahmed T, Eyre P, Wanner A 1979 Determination of pulmonary blood flow by the rebreathing technique in airflow obstruction. Am Rev Respir Dis 120:533

19. Sackner MA, Greenelitch W, Heiman MS, Epstein S, Atkins N 1975 Diffusing capacity, membrane diffusing capacity, capillary blood volume, pulmonary tissue volume, and cardiac output measured by a rebreathing technique. Am Rev Respir Dis 111:157

20. Takezawa J, Miller FJ, O'Neil TJ 1980 Single breath diffusing capacity and lung volumes in small laboratory animals. J Appl Physiol Respir Environ Exercise Physiol 48:1052

21. Triebwasser JH, Johnson RL Jr, Burpo RP, Campbell JC, Reardon WC, Blomquist CG 1977 Non-invasive determinations of cardiac output by a 
modified acetylene breathing procedure utilizing mass spectrometer measurements. Aviation Space Environ Med 48:203

22. Tucker HJ, Murray JF 1973 Effects of end expiratory pressure on organ blood

flow in normal and diseased dogs. J Appl Physiol 34:265

23. Watanabe S, Frank R 1975 Lung volumes, mechanics, and single-breath diffusing capacity in anesthetized cats. J Appl Physiol 38:1148

24. Wilcox RE, Hightower WL, Smith RV 1979 Post-hoc data analysis in biomedical research. Am Lab 11:32

25. Woolverton WC, Bryham KL, Staub NC 1978 Effect of positive pressure breathing on lung lymph flow and water content in sheep. Circ Res 42:550

\title{
Uterine Arterial and Venous Concentrations of Glucose, Lactate, Ketones, Free Fatty Acids, and Oxygen in the Awake Pregnant Guinea Pig
}

\author{
L. L. H. PEETERS, L. MARTENSSON, B. K. VAN KREEL, AND H. C. S. WALLENBURG
}

Department of Obstetrics and Gynecology, Erasmus University Medical School, Dr. Molewaterplein 50, 3015 GE

Rotterdam, The Netherlands

\begin{abstract}
The concentration differences across the pregnant uterus of glucose, lactate, ketoacids, free fatty acids (FFA), and oxygen were determined in 21 chronically catheterized guinea pigs. Polyvinyl catheters were inserted into one of the ovarian veins and the right carotid artery around the 50th day of pregnancy. Postoperative recovery of maternal substrate concentrations in this preparation was evaluated in five animals. Elevated hemoglobin and ketoacid concentrations persisted up to the 4th day after surgery in the awake animal. In 16 animals between 54 and 62 days gestation, arterial and venous blood samples were collected between the 4th and 13th postoperative days. Arteriovenous substrate differences across the pregnant uterus (means \pm SD) were as follows: glucose, 0.87 $\pm 0.22 \mathrm{mM}$; lactate, $0.31 \pm 0.11 \mathrm{mM}$; and oxygen $4.77 \pm$ $0.58 \mathrm{mM}$. There was no significant difference for ketoacids. In 10 animals, plasma FFA concentrations were determined. In nine animals, the arterial concentration was higher suggesting a net uptake of FFA by the pregnant uterus. Lactate production by the uterus accounted for approximately $18 \%$ of uterine glucose uptake if glucose is assumed to be the only source of uterine lactate production. The mean glucose/oxygen quotient across the uterus corrected for lactate output was $0.92 \pm 0.34$. It is concluded that glucose is a major metabolic substrate for the nearterm uterus in the pregnant guinea pig and can account for most of the uterine oxygen consumption. (Pediatr Res 18:1172-1175, 1984)
\end{abstract}

Abbreviations

FFA, free fatty acids

IVC, inferior vena cava

UBF, uteroplacental blood flow
Most of our knowledge of uterine metabolism in pregnancy is derived from experimental studies in ruminants. Only recently has it become technically feasible to perform cardiovascular and metabolic studies in chronically instrumented small mammals, such as the rat (6), the guinea pig (12), and the rabbit (7). Reproduction in these animals differs from that in the sheep with respect to several important variables, such as gestational length, placentation, litter size, fetal growth rate and fetal body composition. For this reason, it may be of interest to repeat in these species physiologic studies performed in pregnant ruminants. Among small mammals, the guinea pig is remarkable in that it produces a relatively large fetal mass with a high fat content ( $10 \%$ as compared with $2 \%$ in the fetal lamb) imposing an important metabolic drain upon the mother (1). We have developed a technique which allows measurement of uterine arterial and venous concentrations of various substrates in the unstressed, awake pregnant guinea pig (14). The present report describes the arteriovenous concentration differences for glucose, lactate, ketoacids, FFA, and oxygen obtained in this model.

\section{MATERIALS AND METHODS}

Twenty-one pregnant albino guinea pigs, bred in our own laboratory facility, were used in this study. The first day of pregnancy was defined as the second day of the opening of the vaginal membrane, provided the breeding was successful. From the 30th day until after completion of the experiments, the animals were kept in individual cages in a controlled environment $\left(19^{\circ} \mathrm{C}, 50 \%\right.$ humidity) with a $13: 11$-light/dark cycle. They were fed commercial guinea pig pellets, hay, and water ad libitum. Twice weekly, vitamin $\mathrm{C}$ and once weekly vitamin $\mathrm{E}$ were added to the drinking water.

Between 48 and 52 days gestation, the animals were anesthesized with ketamine $\mathrm{HCl}\left(30 \mathrm{mg} \cdot \mathrm{kg}^{-1} \mathrm{SC}\right)$ and xylazine $(3 \mathrm{mg}$. $\mathrm{kg}^{-1}$ intramuscular). Using aspectic techniques, a polyvinyl catheter (Bolab Inc., Derry, NH; o.d./i.d., 0.80:0.40 mm) was inserted into a carotid artery and advanced into the ascending aorta. A polyethylene "guide catheter" (Talas, Ommen, Holland; o.d./ i.d., 1.27:0.86 mm) was advanced retrogradely under fluoroscopy from the right jugular vein into the IVC to approximately $1 \mathrm{~cm}$ 